\title{
An analysis of determinants of going concern audit opinion: Evidence from Spain stock exchange
}

\author{
José Luis Gallizo, Ramon Saladrigues \\ Universitat de Lleida (Spain) \\ gallizo@aegern.udl.es, ramon.saladrigues@aegern.udl.cat
}

Received July, 2015

Accepted October, 2015

\section{Abstract}

Purpose: The main objective of this article is to go in-depth into the relationship between going concern audit opinion and certain characteristics of the company and auditor, including financial decline.

Design/methodology/approach: A Logit analysis was carried out in order to enable us to discover the probability of receiving a going concern audit opinion.

Findings: Characteristics of the company and characteristics of the auditor are discussed, and the analysis indicates that it is not financial decline, but rather registering losses and being audited by a small-scale auditor, that increase the likelihood of a company receiving a going concern audit opinion.

Practical implications: The results obtained are interesting for the profession and users because they provide evidence of the reasons that converge in the cases where a going concern audit opinion is included in the auditing reports of companies characterised by being immersed in a financial crisis.

Originality/value: This article considers the circumstances of both the company and the auditing process, which influence the fact that the auditing report includes a going concern audit opinion. In addition, the article includes the financial decline, and let us to analyze if the decline of the company's financial position between t- 1 and t causes the auditor to include a going concern audit opinion.

Keywords: Audit, financial decline, going concern audit opinion 


\section{Introduction}

In compiling financial statements, the presumption that the company will maintain its activity in the future, plays an important role. The going concern accounting principle acts as a basis for most of the assessment and recognition criteria used in accountancy, and therefore, the financial information is drawn up on this hypothesis. It is normal for those users who trust auditors to assess the degree in which this principle has been fulfilled, to consider the going concern audit opinion very important since it can lead to alerting significant uncertainties, such as for example, possible bankruptcy.

In spite of the above, auditors are sometimes reticent about doubting the continuity of the company, (Arnedo, Lizarraga, Sánchez \& Ruiz, 2012) and this suggests that his declarations can bring negative consequences, both for the auditor and the actual company. On the one hand, it would bring the auditor's consideration into question, and on the other hand, including a going concern audit opinion could accelerate the company's bankruptcy process.

Financial information users expect the auditor to inform on a real situation and the company's true and fair view, and if there is financial decline, the auditor will express this in the corresponding auditing report. However, it does not always happen this way, and the auditor can be reticent about including a going concern audit report. True and fair view in auditing means that the financial statements are free from material misstatements and faithfully represent the financial performance and position of the entity.

The reasons for reticence that usually occur in the financial years immediately before a going concern audit opinion, are as follows:

- Pressure from the client, who is aware that a going concern audit report can jeopardise the company's current position even further. The perception by shareholders of a company's negative position can have very serious consequences such as for example, a lack of confidence from the shareholders which could lead to selling shares and therefore, a significant loss of company capital in a very short period. Therefore, the company will try to delay the going concern audit opinion as long as possible, by persuading the auditor and showing him viability plans that project an improvement in the company's position in the mid-term.

- The auditor's confidence in the company who, acting in good faith and rationally, trusts that the company can come out of the difficult situation it is currently in. He will try to delay the going concern audit opinion as much as possible to not jeopardise the company, giving it time to improve its position. Once the auditor determines that the 
crisis the company is in is irreversible, the auditor will include the going concern audit opinion.

- Finally, including a going concern audit opinion can, at the same time, condition the development of the auditing firm. It may happen that an auditing company with a high number of going concern audit opinions in its reports ends up being considered susceptible to them by the companies contracting their services. This could lead to a reduced sales volume in these companies, particularly in small-size firms, because many clients would change to firms that are less likely to have going concern audit reports.

Despite reticences, there comes a time when the decision to include the going concern audit opinion in the report cannot be postponed any longer in terms of risk. This is when the auditor obliges the company to adjust its balance sheets downwards to justify the going concern audit report.

By "adjusting downwards" we basically mean, stricter behaviour from the auditor who encourages revealing hidden liabilities and eliminating overpriced assets that may be reflected in the balance sheet to show a more solvent image.

There are auditors who have proved that including a going concern audit opinion in the report coincides with a sudden decline in the company's financial position (Rosner, 2003). It has been argued that this sudden decline is caused by the demands of the auditor, who forces all the assets and liabilities being reflected in the balance sheet, and their value according to the valuation rules and principles (Arnedo et al., 2012). In these cases, receiving a going concern audit opinion will produce a surprise effect on the information users, as they are not expecting their accounts to decline so suddenly.

In this "paper", we will test, whether in practice, the auditor waits until the last moment before including a going concern audit opinion on the company's future, in accounts that show a sudden financial decline, or whether on the other hand, the financial decline observed in the annual accounts takes place gradually and the auditor acts correctly by including a going concern audit opinion when he really concludes that there is uncertainty regarding the company's continuity.

\section{Aim and hypothesis}

To identify the main causes explaining the probability that a company receives a going concern audit report, taking into account, among the explanatory variables, the fact that the company has experienced a financial decline and, particularly, whether the probability of receiving a going concern audit opinion is greater, when the financial decline occurs in the same year that 
the going concern audit opinion is received. If so, it would mean that the worsened position reflected on the balance sheet, was the result of a "downwards" accounting adjustment forced by the auditor.

Starting with the sample of selected companies with going concern audit report, we will ascertain how many companies have experienced a financial decline in the year that they receive the going concern audit report. The causes of this will be analysed and it will be checked to see whether the decline can be associated to a company profile or pattern, indicating a general formula, or whether they are simply isolated cases.

\section{Sample and methodology}

To conduct the study a sample has been used dating from 2012, with a total of 48 companies which have been divided into two groups: in 24 of them the auditor includes a going concern audit opinion in the auditing report in year $\mathrm{t}$, and the other 24 did not receive a going concern audit opinion. This last group will be the control sample.

We focus on analysing the relationship between the presence of decline and receiving a going concern audit opinion. Once these two lists of companies are obtained, they will be paired up according to turnover figures, size, sector and year the report was issued, so that the two groups of companies are comparable and the conclusions of the study more realistic. We will take the annual accounts of each company in the year the going concern audit opinion is received and compare them with those of the year immediately before.

In this study, the probability of receiving a going concern audit report is determined by indicators explaining the financial position of the companies and other independent variables. If the financial indicators show adverse results, we can affirm that there is a decline in the company accounts. The financial indicators will form the first group of variables associated with the company's behaviour.

\subsection{Independent variables}

We can distinguish two types of independent variables; the economic-financial variables that take information from the financial statements of entities, and the variables associated with the auditor's activity.

With respect to the former, previous studies (Jones, 1987; Bellovary, Giacomino \& Akers, 2007) indicate profitability, indebtedness and the company's liquidity as key factors in the advance detection of the inclusion of going concern audit opinions. On the basis of previous studies, in this work the following variables have been selected: 
- Return on Assets (ROA). Calculated as the net result between the total assets. We expect a negative ratio (or the other way around) with respect to the probability of receiving a going concern audit opinion, i.e., the more positive the economic profitability ratio, the lower the probability of the company receiving a going concern audit opinion.

- Short-term Debt Ratio (Debt). This will be the short-term indebtedness ratio, since this is the biggest risk and the most usual among Spanish companies. Short-term debts are divided between the total debt and obviously, the expected ratio regarding the probability of receiving a going concern audit opinion, is positive.

- Current Ratio (CR). This is calculated by finding the ratio resulting from dividing the current assets among the current liabilities. There are some exceptions, but generally a negative ratio is expected with regard to the probability of receiving a going concern audit opinion.

- Liquidity Ratio (LIQ). Calculated on the basis of the ratio of the amount available between the current assets. The expected ratio with respect to receiving the going concern audit opinion is negative.

- Size (SIZE). This will be the measurement referring to the size of the company, expressed in volume of assets. It will be expressed with the Naperian logarithm function to harmonise the units.

- At the same time, a dichotomous variable is added that tells us if the company has had losses or negative financial year results (LOSS). It will take value 1 if it has had losses, or value 0 if it has not.

Empirical research works that have analysed the circumstances that lead the auditor to issue a going concern audit opinion, highlight the company's financial position as the main explanatory factor (Geiger \& Raghunandan, 2002).

Finally, regarding the economic-financial variables that take information from the financial statements of entities, the "financial decline" variable has been taken into account. This variable is developed in the section 3.2 below.

The second group of variables that will be included in the study are exogenous variables that will gather the defining characteristics associated with the work of the auditor, both in relation to his competence and his independence. The variables corresponding to this group, are as follows:

- Big auditor (BIG): this is a dichotomous variable that will take value 1 if the auditor belongs to one of the four multinational auditing firms, the so-called "Big Four". 
Namely: Deloitte, PricewaterhouseCooppers, Ernst and Young and KPMG. The greater international presence of the big firms has enhanced the reputation of these companies. This formation of an image of a superior brand has been defended by studies showing that if it is one of the four big ones that is auditing the company accounts, the company will be more likely to receive a going concern audit opinion, and also higher fees will be paid to the auditors. (Defond, Raghunandan \& Subramanyam, 2002). Therefore, we expect a positive ratio between the probability of receiving a going concern audit opinion and the BIG variable.

- The delay in issuing the auditing report (DEL). The decision to issue a non-clean report occurs after intense meetings between the company management and the auditor, whereby, we can understand that if there is a certain delay in issuing the report, the probability of this report including a going concern audit opinion increases. Also, the auditor will intensify the tests to be carried out if he detects possible continuity problems, which will increase the delay in issuing the report (Geiger, Raghunandan \& Rama, 2005). This variable will result from calculating the days between the close of the financial year and the date the auditing report is signed. This variable will tend to have a positive ratio with respect to the probability of receiving a going concern audit opinion.

- The relative size of the client (TRC). When the client represents a high percentage of the auditing firm's turnover, the auditor in charge of the process will be more reticent to issuing a going concern audit opinion than if this percentage were low. This data is calculated by dividing the client's sales figure between the auditing firm's total turnover volume. The ratio between the TRC variable and the probability of receiving a going concern audit opinion is negative, since the greater the TRC, the lower the probability of receiving a going concern audit opinion.

Thanks to the information from the annual accounts and the auditing firms, all the independent variables included in this model could be calculated accurately.

\subsection{Financial decline}

In analysing the causes explaining the probability of a company receiving a going concern audit report, we will have to take into account the fact that the company has experienced a financial decline. In order to determine the financial decline of the companies in the sample, the Altman Z-score has been used (Altman, 1993)

The Z-Score is a linear combination of five financial ratios, each one weighted by a coefficient, aimed at determining whether the probability of a company going bankrupt exists in the 
future. There are several possible coefficient combinations that would vary according to the type of companies. In our case we will use the combination of private and large size companies. The Altman Z-Score model used is:

$$
Z=1.2 T 1+1.4 T 2+3.3 T 3+0.6 T 4+0.999 T 5
$$

where:

T1 = Working capital / Total assents

$\mathrm{T} 2$ = Retained earnings / Total assets

$\mathrm{T} 3$ = Earnings before interest and tax / Total assets

T4 = Market value of equity / Total assets

$\mathrm{T} 5$ = Sales/ Total assets

If the value $Z$ is:

$<1,3$ : the company is likely to go bankrupt in the future. The further $Z$ is from this figure, tending to go to negative values, the higher this probability is.

$>1,3$ : there is no probability that the company will go bankrupt in the future. The further $Z$ is from this figure tending to go towards infinite, the lower this probability will be.

The data was obtained from the annual accounts of each company. They contained all the data regarding the balance sheet and the profit and loss account. To find the market value, which does not appear in the annual accounts, we used the continuous market and did the SharePrice* NumberShares calculation for each company.

\section{The logit model and the results}

We use a logit model to calculate the probability that a company showing decline in its accounting statements is going to receive a going concern audit opinion. The logit model is considered appropriate because it allows us to measure the probability of a binary variable (companies with going concern audit opinion and companies without going concern audit opinion) and with the presence of qualitative type data.

All the data necessary for calculating the values the variables take, as well as the auditing reports, were obtained from the annual report from each of the 48 companies in the sample. Various estimates were obtained on the combined effects using a logit model taking all the variables at the same time, typifying the quantitative variables beforehand and applying forward and backward variable selection procedures. 
The results of the logit model are as follows:

$$
\begin{gathered}
\operatorname{logit}(P(S E F=S i))=-2.989 * Z C R-15.020 * Z L Q I+0.513 * Z S I Z E-24.237 * Z T R C-0.242 * Z \text { Delay } \\
+0.266 * Z \text { Financial_decline }+130.117 * \text { LosS }-137.116 * Z \text { Big }-1.007 * Z R O A
\end{gathered}
$$

\begin{tabular}{|c|c|c|c|}
\hline & Chi-square & gl & Sig. \\
\hline Model & 54.869 & 9 & .000 \\
\hline
\end{tabular}

\subsection{Tests on the model coefficients}

Table 1. Omnibus tests on the model coefficients

The tests on the model coefficients show that the results obtained are significant.

\begin{tabular}{|r|r|r|r|}
\hline Step & $\mathbf{- 2 ~ l o g}$ likelihood & $\mathbf{R}^{\mathbf{2}}$ de Cox y Snell & $\mathbf{R}^{\mathbf{2}}$ de Nagelkerke \\
\hline 1 & 11.673 & .681 & .908 \\
\hline
\end{tabular}

Table 2. Summary of the model

In the summary of the model, it can be seen that the adjustment measurements are good,

\begin{tabular}{|c|c|c|c|c|c|}
\hline & \multirow{3}{*}{\multicolumn{2}{|c|}{ Observed }} & \multicolumn{3}{|c|}{ Prediction } \\
\hline & & & \multicolumn{2}{|c|}{$\begin{array}{l}\text { Going concern } \\
\text { audit opinion }\end{array}$} & \multirow{2}{*}{$\begin{array}{c}\text { Correct } \\
\text { percentage }\end{array}$} \\
\hline & & & No & Yes & \\
\hline \multirow{3}{*}{ Step 1} & \multirow{2}{*}{$\begin{array}{l}\text { Going concern } \\
\text { audit opinion }\end{array}$} & No & 23 & 1 & 95.8 \\
\hline & & Yes & 0 & 24 & 100.0 \\
\hline & \multicolumn{2}{|c|}{ Overall percentage } & & & 97.9 \\
\hline
\end{tabular}
with high values for the R2 coefficients.

Table 3. Classification Table

Also, it can be seen that the model predicts well with $97.9 \%$ correct scores.

\begin{tabular}{|c|r|r|r|r|r|r|}
\cline { 2 - 7 } \multicolumn{1}{c|}{} & \multicolumn{1}{c|}{ B } & \multicolumn{1}{c|}{ E.T. } & Wald & \multicolumn{1}{c|}{ gl } & \multicolumn{1}{c|}{ Sig. } & \multicolumn{1}{c|}{ Exp(B) } \\
\hline ZCR & -2.989 & 3.975 & 0.565 & 1 & .452 & .050 \\
\hline ZLIQ & -15.020 & 24.610 & 0.372 & 1 & .542 & .000 \\
\hline ZSize & 0.513 & 1.267 & 0.164 & 1 & .686 & 1.671 \\
\hline ZTRC & -24.237 & 73.060 & 0.110 & 1 & .740 & .000 \\
\hline ZDelay & -0.242 & 0.994 & 0.060 & 1 & .807 & .785 \\
\hline ZFinancial_Decline & 0.266 & 0.996 & 0.071 & 1 & .789 & 1.305 \\
\hline LosS & 130.117 & 2644.252 & 0.002 & 1 & .961 & $3.229 \mathrm{E}+56$ \\
\hline Big & -137.116 & 2644.791 & 0.003 & 1 & .959 & .000 \\
\hline ZROA & -1.007 & 1.198 & 0.706 & 1 & .401 & .365 \\
\hline
\end{tabular}

Table 4. Variables in the equation

The independent quantitative variables are typified. 
Table 4 shows the variables in the equation and shows that the probability of a going concern audit opinion not occurring increases if the analysed companies have:

- Greater current ratio

- Greater liquidity

- Smaller size

- Larger relative size of the client in the auditing firm

- Greater delay in the auditing report

- Less financial decline

- No losses

- Audits by a large auditing firm

- Greater return on assets

\begin{tabular}{|r|r|r|r|}
\hline Step & Chi square & gl & Sig. \\
\hline 1 & 3.049 & 7 & .880 \\
\hline
\end{tabular}

Table 5. Hosmer and Lemeshow test

\begin{tabular}{|c|c|c|c|c|c|c|}
\hline & \multicolumn{2}{|c|}{$\begin{array}{c}\text { Going concern audit } \\
\text { opinion }=\text { No }\end{array}$} & \multicolumn{2}{|c|}{$\begin{array}{c}\text { Going concern audit } \\
\text { opinion }=\text { Yes }\end{array}$} & \multirow[t]{2}{*}{ Total } \\
\hline & & Observed & Expected & Observed & Expected & \\
\hline \multirow{9}{*}{ Step 1} & 1 & 5 & 5.000 & 0 & .000 & 5 \\
\hline & 2 & 5 & 5.000 & 0 & .000 & 5 \\
\hline & 3 & 5 & 5.000 & 0 & .000 & 5 \\
\hline & 4 & 5 & 5.000 & 0 & .000 & 5 \\
\hline & 5 & 3 & 3.006 & 2 & 1.994 & 5 \\
\hline & 6 & 0 & .712 & 5 & 4.288 & 5 \\
\hline & 7 & 1 & .262 & 4 & 4.738 & 5 \\
\hline & 8 & 0 & .020 & 5 & 4.980 & 5 \\
\hline & 9 & 0 & .000 & 8 & 8.000 & 8 \\
\hline
\end{tabular}

Table 6. Contingency table for the Hosmer and Lemeshow test

The Hosmer Lemeshow adjustment measurement is appropriate, whereby the hypothesis that the model is true is not rejected, given that the p-value of the contrast is high.

\subsection{Logistic regression with selection of variables}

By applying a forward variables selection procedure, taking the conditional likelihood as the selection criteria and with $p$-value entrance and exit tolerances of 0.05 and 0.1 , respectively, 
the results show that, when determining which variables influence the auditor the most to issue a going concern audit opinion, these are as follows:

- Having losses, and

- Size of the auditing firm

So that having losses and being auditing by a small auditing firm means that it is more likely that a company receives a going concern audit opinion.

\begin{tabular}{|c|c|c|c|c|}
\hline \multirow{3}{*}{\multicolumn{2}{|c|}{ Observed }} & \multicolumn{3}{|c|}{ Prediction } \\
\hline & & \multicolumn{2}{|c|}{$\begin{array}{l}\text { Going concern audit } \\
\text { opinion }\end{array}$} & \multirow{2}{*}{$\begin{array}{c}\text { Correct } \\
\text { percentage }\end{array}$} \\
\hline & & No & Yes & \\
\hline \multirow{2}{*}{$\begin{array}{l}\text { Going concern audit } \\
\text { opinion }\end{array}$} & No & 20 & 4 & 83.3 \\
\hline & Yes & 0 & 24 & 100.0 \\
\hline \multicolumn{2}{|l|}{ Overall percentage } & & & 91.7 \\
\hline
\end{tabular}

Table 7. Classification table

The adjustment values are still appropriate both with respect to the $\mathrm{R}$ coefficients and the predictive behaviour ( $91.7 \%$ success), and with respect to the Hosmer and Lemeshow contrast.

Model equation:

$$
\operatorname{logit}(P(S E F=S i))=22.268 * \text { LoSS }-21.495 * \text { ZBig }
$$

Tables 8 and 9 show the descriptive statistics of the variables included in the study. The model indicates the differences in the average, between the group of companies that have received a going concern audit opinion (Yes) and those that have not received one (No), and the greater or lesser differences reveal the importance of the variables.

\begin{tabular}{|c|r|r|r|r|r|}
\cline { 2 - 6 } \multicolumn{1}{c|}{} & N & Minimum & Maximum & Average & \multicolumn{1}{c|}{ Dev. typ. } \\
\hline ROA & 48 & -.6890 & .3517 & -.057310 & .1942273 \\
\hline Short-term debt ratio & 48 & .0499 & .9984 & .530996 & .2900421 \\
\hline Current Ratio (CR) & 48 & .1075 & 31.9642 & 2.005526 & 4.6502313 \\
\hline Liquidity ratio & 48 & .0000 & 9.2445 & .391221 & 1.3508773 \\
\hline Size (Ln(Assets) & 48 & 8.9606 & 16.4844 & 12.831141 & 1.6952470 \\
\hline 100* Relative size of & 48 & .0000 & 95.1904 & 2.442454 & 13.7737027 \\
\hline Client & 48 & 20 & 333 & 90.52 & 53.645 \\
\hline Delay in Report & 48 & $0.00 \%$ & $100.00 \%$ & $52.08 \%$ & $50.49 \%$ \\
\hline Loss & 48 & $0.00 \%$ & $100.00 \%$ & $75.00 \%$ & $43.76 \%$ \\
\hline Auditoryyyyyy Size (BIG) & 48 & & & &
\end{tabular}

Table 8. Descriptive statistics 


\begin{tabular}{|c|c|c|c|c|c|}
\hline & $\begin{array}{l}\text { Going } \\
\text { concern } \\
\text { audit } \\
\text { opinion }\end{array}$ & $\mathbf{N}$ & Average & Dev. Typ. & $\begin{array}{c}\text { Error typ. } \\
\text { Of the } \\
\text { average }\end{array}$ \\
\hline \multirow{2}{*}{ ROA } & No & 24 & .051642 & .1023055 & .0208830 \\
\hline & Yes & 24 & -.0166263 & .2045701 & .0417577 \\
\hline \multirow{2}{*}{ Short-term debt ratio } & No & 24 & .535541 & .2879328 & .0587740 \\
\hline & Yes & 24 & .526450 & .2982582 & 0.608817 \\
\hline \multirow{2}{*}{ Current Ratio (CR) } & No & 24 & 1.682411 & 1.8206038 & .3716292 \\
\hline & Yes & 24 & 2.328640 & 6.3762859 & 1.3015539 \\
\hline \multirow{2}{*}{ Liquidity ratio } & No & 24 & .313330 & .4406644 & .0899502 \\
\hline & Yes & 24 & .469113 & 1.8767617 & .3830924 \\
\hline \multirow{2}{*}{ Loss } & No & 24 & $12.50 \%$ & $33.78 \%$ & $6.90 \%$ \\
\hline & Yes & 24 & $91.67 \%$ & $28.23 \%$ & $5.76 \%$ \\
\hline \multirow{2}{*}{ Size (Ln(Assets)) } & No & 24 & 13.185237 & 1.6075743 & .3281447 \\
\hline & Yes & 24 & 12.477045 & 1.7397442 & .3551238 \\
\hline \multirow{2}{*}{$\begin{array}{c}\text { 100* Relative size of } \\
\text { Client }\end{array}$} & No & 24 & 4.675935 & 19.4142754 & 3.9629224 \\
\hline & Yes & 24 & .208973 & .5945635 & .1213648 \\
\hline \multirow{2}{*}{ Auditor Size (BIG) } & No & 24 & $95.83 \%$ & $230.41 \%$ & $4.17 \%$ \\
\hline & Yes & 24 & $54.17 \%$ & $50.90 \%$ & $10.39 \%$ \\
\hline \multirow{2}{*}{ Delay in Report } & No & 24 & 79.04 & 47.717 & 9.740 \\
\hline & Yes & 24 & 102.00 & 57.695 & 11.777 \\
\hline
\end{tabular}

Table 9. Group statistics

Having losses in the year when the report is made is the most important variable. It is observed that $91.67 \%$ of the companies with going concern audit opinion had shown losses.

Also, significant differences are observed in the average in return on assets, Current Ratio, Liquidity ratio and the Relative size of the Client (where it is higher in the companies that have not going concern audit opinion). Also, between the companies that have not received a going concern audit opinion, $95.83 \%$ were audited by large auditing firms and the reports including a going concern audit opinion were delayed in time with respect to those who do not have a going concern audit opinion. The differences in the average are not significant in the Shortterm debt ratio.

\begin{tabular}{|c|c|c|c|c|c|c|c|}
\hline & & & \multicolumn{4}{|c|}{ Auditor*Losses } & \multirow[b]{2}{*}{ Total } \\
\hline & & & $\begin{array}{c}\text { Small } \\
\text { without } \\
\text { losses }\end{array}$ & $\begin{array}{l}\text { Small with } \\
\text { losses }\end{array}$ & $\begin{array}{c}\text { Big } \\
\text { without } \\
\text { losses }\end{array}$ & $\begin{array}{l}\text { Big with } \\
\text { losses }\end{array}$ & \\
\hline \multirow{6}{*}{$\begin{array}{l}\text { Going concern } \\
\text { audit opinion }\end{array}$} & \multirow{3}{*}{ No } & Recount & 1 & 0 & 20 & 3 & 24 \\
\hline & & $\begin{array}{c}\% \text { within } \\
\text { Auditor*Losses }\end{array}$ & $33.33 \%$ & $0.00 \%$ & $100.00 \%$ & $18.75 \%$ & $50.00 \%$ \\
\hline & & $\%$ of the total & $2.08 \%$ & $0.00 \%$ & $41.67 \%$ & $6.25 \%$ & $50.00 \%$ \\
\hline & \multirow{3}{*}{ Yes } & Recount & 2 & 9 & 0 & 13 & 24 \\
\hline & & $\begin{array}{c}\text { \% within } \\
\text { Auditor*Losses }\end{array}$ & $66.67 \%$ & $100.00 \%$ & $0.00 \%$ & $81.25 \%$ & $50.00 \%$ \\
\hline & & $\%$ of the total & $4.17 \%$ & $18.75 \%$ & $0.00 \%$ & $27.08 \%$ & $50.00 \%$ \\
\hline \multirow{3}{*}{\multicolumn{2}{|c|}{ Total }} & Recount & 3 & 9 & 20 & 16 & 48 \\
\hline & & $\begin{array}{c}\% \text { within } \\
\text { Auditor*Losses }\end{array}$ & $100.00 \%$ & $100.00 \%$ & $100.00 \%$ & $100.00 \%$ & $100.00 \%$ \\
\hline & & $\%$ of the total & $6.25 \%$ & $18.75 \%$ & $41.67 \%$ & $33.33 \%$ & $100.00 \%$ \\
\hline & & & APO & AP1 & AP2 & AP3 & \\
\hline
\end{tabular}

Table 10. Going concern audit opinion vs. auditor size and losses 
Table 10 shows the qualitative variables auditor size and company with loses with crossed frequency data. It is significant to see that $100 \%$ of the cases in the sample where the auditor is a small firm and the company shows losses, have received a going concern audit opinion.

\subsubsection{Influence of $R O A$}

In previous studies (Jones, 1996) it has been observed that the return on assets (ROA), is one of the key factors in the advance detection of a crisis within a business. Our table shows that the more positive the ROA ratio, the lower the probability of the company receiving a going concern audit opinion.

Table 11 shows that, really, having lower economic profitability makes it more likely that the auditor will issue a going concern audit opinion, and this confirms the presumption that low profitability is a factor for the advance detection of a going concern audit opinion.

\begin{tabular}{|c|c|c|c|c|c|c|}
\hline & \multicolumn{2}{|c|}{$\begin{array}{c}\text { Going concern audit } \\
\text { opinion }=\text { No }\end{array}$} & \multicolumn{2}{|c|}{$\begin{array}{l}\text { Going concern audit } \\
\text { opinion }=\text { Yes }\end{array}$} & \multirow[t]{2}{*}{ Total } \\
\hline & & Observed & Expected & Observed & Expected & \\
\hline \multirow{10}{*}{ Step 1} & 1 & 4 & 4.662 & 1 & .338 & 5 \\
\hline & 2 & 5 & 3.941 & 0 & 1.059 & 5 \\
\hline & 3 & 5 & 3.606 & 0 & 1.394 & 5 \\
\hline & 4 & 4 & 3.391 & 1 & 1.609 & 5 \\
\hline & 5 & 4 & 3.107 & 1 & 1.893 & 5 \\
\hline & 6 & 0 & 2.545 & 5 & 2.455 & 5 \\
\hline & 7 & 1 & 1.771 & 4 & 3.229 & 5 \\
\hline & 8 & 1 & .792 & 4 & 4.208 & 5 \\
\hline & 9 & 0 & .167 & 5 & 4.833 & 5 \\
\hline & 10 & 0 & .019 & 3 & 2.981 & 3 \\
\hline
\end{tabular}

Table 11. Contingency table for the Hosmer and Lemeshow test

\begin{tabular}{|c|c|c|c|c|c|c|}
\hline & \multirow{3}{*}{\multicolumn{2}{|c|}{ Observed }} & \multicolumn{4}{|c|}{$\begin{array}{l}\text { Prediction } \\
\end{array}$} \\
\hline & & & \multicolumn{2}{|c|}{$\begin{array}{l}\text { Going concern audit } \\
\text { opinion }\end{array}$} & \multirow{2}{*}{\multicolumn{2}{|c|}{$\begin{array}{c}\text { Correct } \\
\text { percentage }\end{array}$}} \\
\hline & & & No & Yes & & \\
\hline \multirow{3}{*}{ Step 1} & \multirow{2}{*}{$\begin{array}{c}\text { Going } \\
\text { concern } \\
\text { audit } \\
\text { opinion }\end{array}$} & No & 22 & & 2 & 91.7 \\
\hline & & Yes & 5 & & 19 & 79.2 \\
\hline & \multicolumn{2}{|c|}{ Overall percentage } & & & & 85.4 \\
\hline
\end{tabular}

Table 12. Classification table 


\subsubsection{Size of the auditor}

Various auditors have empirically defended that the companies audited by a large multinational show less levels of manipulation and are revealed as being more likely to receive reports with going concern audit opinion (Defond et al., 2002).

However, our study obtained a result that points in the other direction, and which seems to indicate that being audited by a small auditor makes it more likely to obtain a going concern audit opinion. (Table 13). One explanation that would help to understand this discrepancy is that the sample contains Spanish listed companies, whose analysed years coincide with the recession, and that the companies in the sample most affected by the recession were audited by firms not included among the four big ones. Therefore, vis-à-vis this result, it is worth asking if the large auditing firms intervene with a prior selection of the quality of its clients, or whether companies with financial difficulties prefer not to look for an auditor in the group of the big multinational firms because of their possibly inflexible attitude towards account manipulation, as well as their higher fees. This type of checks could be addressed in future works, perhaps with a wider sample of companies and with a period of years that reflect an improvement in the financial variables of the companies.

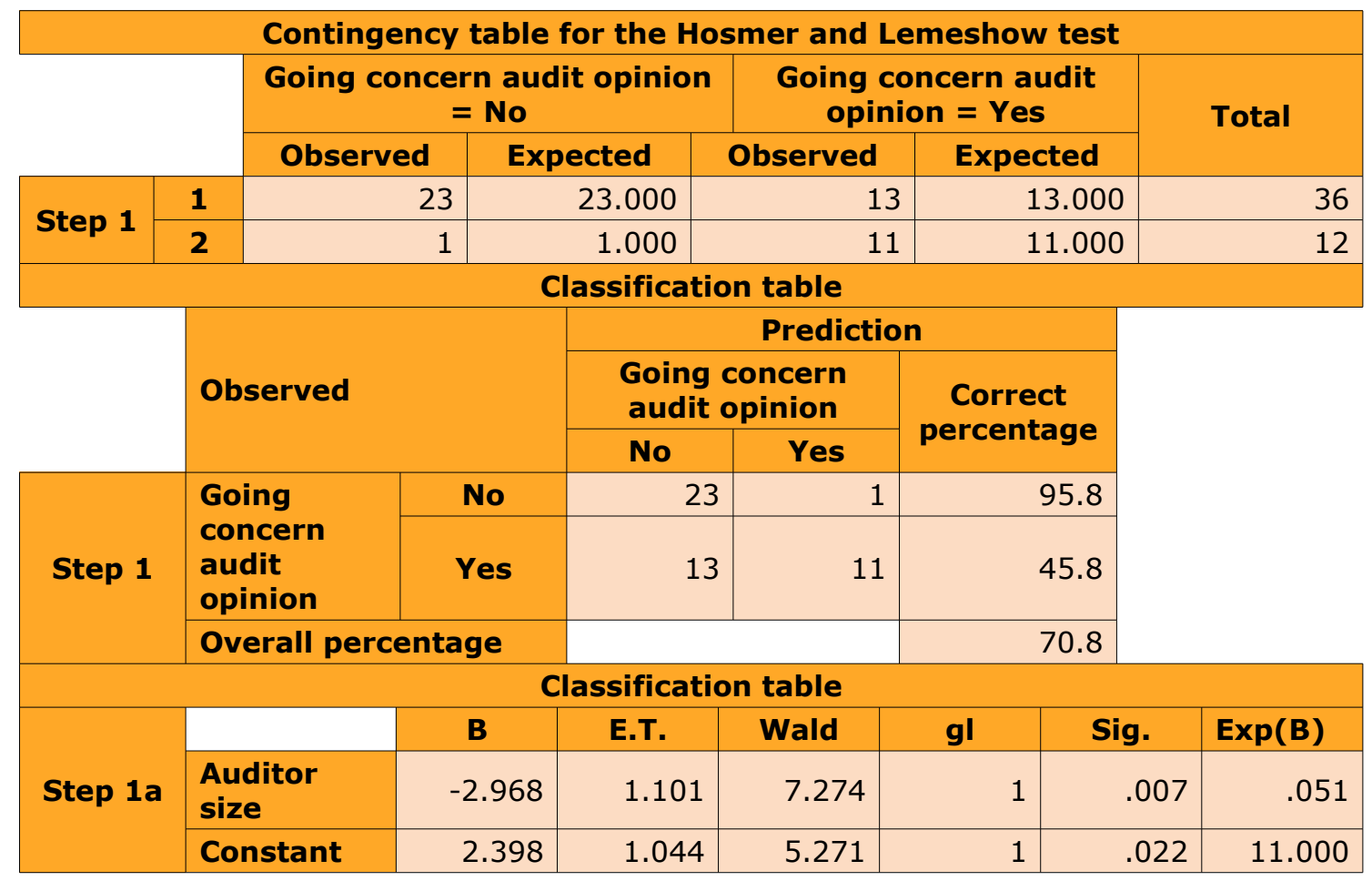

Table 13. Influence of the auditor size 


\subsubsection{Influence of the presence of losses}

As already discussed, having losses in the year when the report is made is the most determining variable. It is observed that $91.7 \%$ of the companies that have going concern audit opinion, show losses (Table 14).

This result coincides with previous studies (Krishnan, Krishnan \& Stephens, 1996) (Citron \& Taffler, 1992) that conclude that losses is the variable that better explain the probability of obtaining a going concern audit opinion.

That could be because auditor detect creative accounting practices or any kind of financial statements manipulation, or because the absence of benefits indicates the inability to continue their market activities, influencing auditors' going concern opinion.

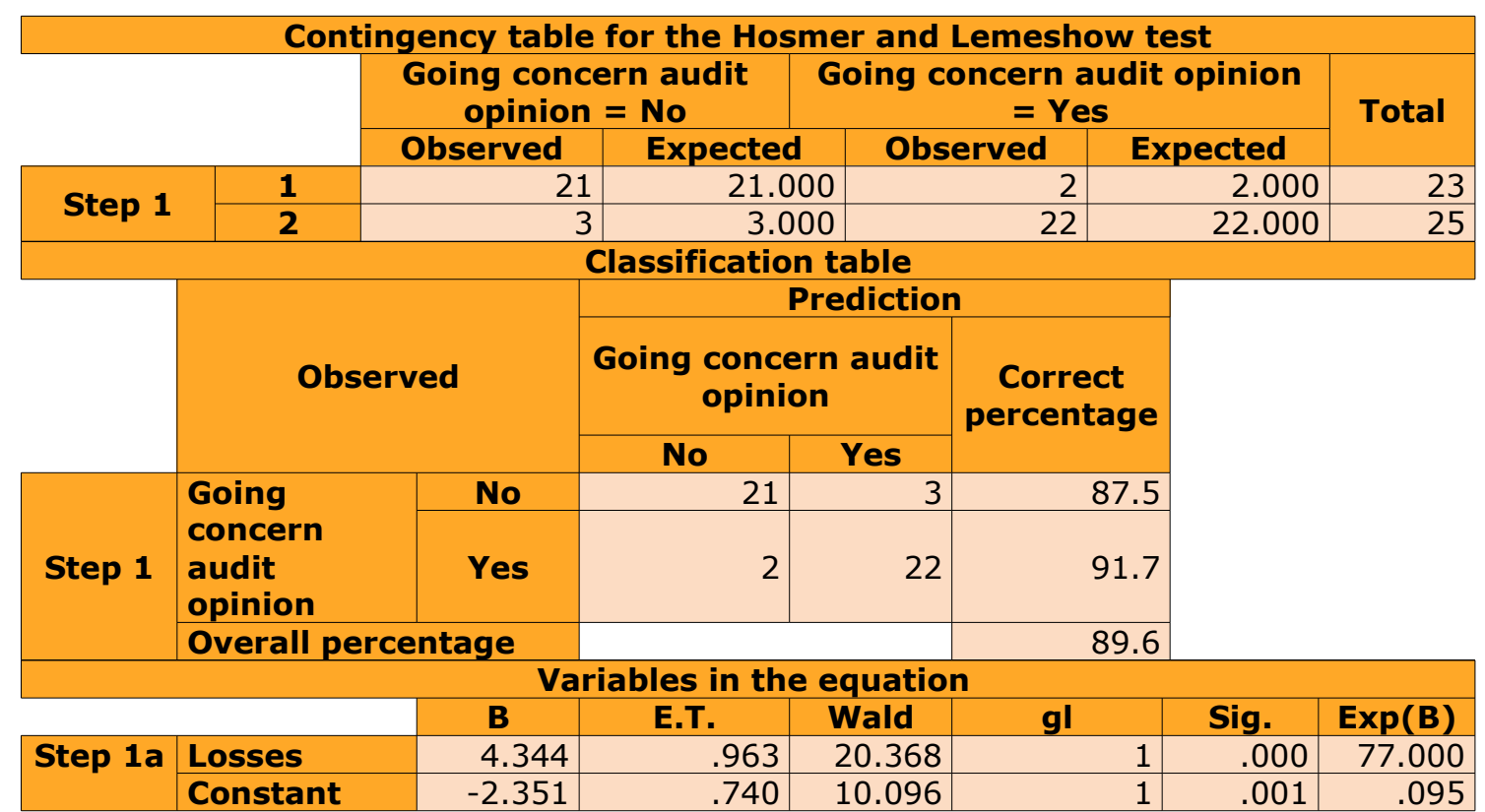

Table 14. Influence of losses

\section{Conclusions}

This work comes under the framework of the study on the Going Concern and on the auditor's obligation to determine whether or not there is any material uncertainty to the company staying in business (NIA-570). We consider the circumstances or qualities of both the company and the auditing process, which influence the fact that the auditing report includes a going concern audit opinion. 
We have analysed the variables that determined including a going concern audit opinion, and particularly if the decline of the company's financial position between $t-1$ and $t$ causes the auditor to include a going concern audit opinion.

The empirical work has been developed on the basis of a sample of 48 companies where 24 of them had a going concern audit report in year $t$ and the other 24 did not. We have formulated a multivariant logit analysis, including among the variables the decline in the financial position in the year on which the auditing report is issued.

From the analysis carried out, it is obtained that it is not the sudden financial decline, but having losses and being audited by a small auditing firm, that makes it likely that a company receives a going concern audit opinion and, to a lesser extent, when the relative size of the client is small. This way, the increase in the probability of obtaining a going concern audit opinion would not be based on the sudden decline in the company's financial position, but on the persistence of losses. This is the most important reason that puts the company's continuity at risk, and which would have immediate consequences like the removal of tax credits. Also, contrary to expectations, the professional auditor being a small firm has not proved to be a limiting circumstance to receiving a going concern audit opinion, and this could indicate that auditors, irrespective of belonging or not to one of the big auditing companies, intervene as professionals and there are no differences between them insofar as issuing a report with a going concern audit opinion.

As for profitability, we have observed that the more profitable a company, the lower the probability of receiving a going concern audit opinion, since a profitable company does not show losses and therefore has no continuity problems. Also, the larger the size of the auditing company, the lower the probability of it including a going concern audit opinion, which could indicate that the large size auditing firms can select their clients and, therefore, they can impose a lower number of going concern audit opinions.

In short, the most important indicator that the auditor has to bear in mind for including a going concern audit opinion is the continued existence of losses. In cases where these losses have remained hidden by manipulating the results from previous years, this fact is likely to cause the auditor to include a going concern audit opinion in the year the report is issued, when the company position, due to a lack of perspectives or viability plan, prevents it from continuing in the future.

The results obtained are interesting for the profession and users because they provide evidence of the reasons that converge in the cases where a going concern audit opinion is included in the auditing reports of companies characterised by being immersed in a financial crisis. 


\section{References}

ALTMAN, E. (1993). Corporate Financial Distress and Bankrupty (2nd ed.). New York: John Wiley \& Sons. Available online in: http://pages.stern.nyu.edu/ ealtman/PredFnclDistr.pdf

ARNEDO, L.; LIZARRAGA, F.; SÁNCHEZ, S.; RUIZ, E. (2012). Las expectativas del usuario ante la salvedad al principio de empresa en funcionamiento. Evidencia empírica del fenómeno de la profecía autocumplida para el caso español. Revista Española de Financiación y Contabilidad, 154: 263-289.

BELlovarY, J.L.; GIACOMINO, D.E.; AKERS, M.D. (2007). A Review of Bankruptcy Prediction Studie: 1930 to present. Journal of Financial Education, 33(Winter): 1-43.

CITRON, D.; TAFFLER, R. (1992). The audit report under going concern uncertainties: an empirical analysis. Accounting and Business Research, 22: 337-345.

http://dx.doi.org/10.1080/00014788.1992.9729449

DEFOND, M.; RAGHUNANDAN, K.; SUBRAMANYAM, K. (2002). Do non-audit service fees impair auditor independence? Evidence from going concern audit opinions. Journal of Accounting Research, 40(4): 1.247-1.274.

GEIGER, M.A.; RAGHUNANDAN, K. (2002). Auditor Tenure and Audit Reporting Failures. Auditing: A Journal of Practice and Theory, 21(1): 67-78.

http://dx.doi.org/10.2308/aud.2002.21.1.67

GEIGER, M.A.; RAGHUNANDAN, K.; RAMA, D.V. (2005). Recent changes in the association between bankruptcies and prior audit opinions. Auditing: A Journal of Practice \& Theory, 24(1): 21-35. http://dx.doi.org/10.2308/aud.2005.24.1.21

JONES, F.L. (1987). Current Techniques in Bankruptcy Prediction. Journal of Accounting Literature, 6: 131-164.

JONES, F.L. (1996). The information content of the auditor's going concern evaluation. Journal of Accounting and Public Policy, 15(1): 1-27. http://dx.doi.org/10.1016/0278-4254(95)00062-3

KRISHNAN, J.; KRISHNAN, J.; STEPHENS, R. (1996). The simultalleous relation between auditor swatching and audit opinion: and empirical analysis. Accounting and Business Research, 26: 224-236. http://dx.doi.org/10.1080/00014788.1996.9729513

ROSNER, R.L. (2003). Earnings manipulation in failing firms. Contemporary Accounting Research, 20(2): 361-408. http://dx.doi.org/10.1506/8EVN-9KRB-3AE4-EE81

Intangible Capital, 2016 (www.intangiblecapital.org) 